\title{
Implementation of Government Crisis Communication During The Covid-19
}

\author{
Rastri Kusumaningrum ${ }^{1 *}$ Lina Aryani ${ }^{2}$ \\ ${ }^{1,2}$ Faculty of Social and Political Sciences, Universitas Singaperbangsa Karawang, Jawa Barat, Indonesia \\ "Corresponding author. Email: rastri.kusumaningrum@fisip.unsika.ac.id
}

\begin{abstract}
The spread of the covid-19 has become a major crisis for countries in the world and changed the government policies pattern to handling the crisis proactively. Crisis communication strategies by the government have to be important thing among policy makers and also community. The pattern of communication established between the central and regional governments in policy making and delivering the quality information to the public is a form of government's preparedness and seriousness for handling the crisis. This article examines the implementation of the crisis communication aimed at handling the spread of covid-19 and preventing the hoax information from mass media that can make the communities chaos, applying a framework developed using indicators derived from the strategic planning and quality literature. Results show that there are clear indices of formal rules governing the practice of communication flow or information policy. The covid-19 handling acceleration task force established by the government, both at the central and regional levels, as the main reference to the government in conveying the information about the covid-19 to public, is one of efforts to minimize the misinformation developing within the community. Although the mechanism is being applied to handle the crisis, the practices are still far from being fully systematized. The analysis provides evidence that the government has full attention and professionalism to manage the crisis and to save the public from misinformation. The article describes that the government policies made with the right communication will be able to manage the crises effectively.
\end{abstract}

Keywords: Covid-19, crisis communication, crisis management, government, policy

\section{INTRODUCTION}

The COVID-19 coronavirus pandemic has impacted all aspects of energetic and social life dimensions. This outbreak was deemed a pandemic by the World Health Organization (WHO) on 11th March 2020. To date, there have been cases confirmed in at least 203 countries, areas or territories, according to the World Health Organization. The COVID-19 pandemic has caused unprecedented measures to be taken by many countries, such as travel restrictions and restrictions on social gatherings [1]. The unprecedented circumstances and impacts of the COVID19 , demonstrate signs that this crisis is not only different, but it can have profound and long-term structural and transformational changes to public activity and industry [2].

The covid impacts on health, healthcare, economy, labor market, supply chain, work and home life are manifold and potentially lasting for a long time. Even after the pandemic passes, there may be permanent changes to workplaces and jobs, with some organizations already planning for a future with significantly expanded [relative to pre-COVID] or even nearly permanent work-fromhome for its employees [3]. In his research [3], Venkatesh also mentions that with the advent of covid, the role of technology has permeated all aspects of our lives. Several organizations have moved almost entirely to distributed (remote, virtual) work, even more important role in social lives and entertainment. Technology influences various facets of work and home life, it can be used to help and also it can cause harm. Adverse effects of technology are mental disorders caused by panic over about the covid-19 which was also triggered by the news through the mass media which made this crisis situation more chaotic. It means all people need to refine their information consumption from mass media about the covid to keep their mental health during the pandemic.

These days, we are faced with a lot of information regarding the COVID-19 from different sources. However, fake information, gossip and rumors are more common than factual information. The advantages of social media notwithstanding, they are also a major source of misinformation. The result of observation shows that 
social media exposure has been associated with anxiety and depression among the users. Increasing fear of the COVID-19 pandemic due to misinformation is another disadvantage of the social media platforms. Gossip and rumors not only diminishes mental health status, but also may interfere with the diagnosis processes, the prevention and the treatment of the COVID-19. Therefore, planning strategies to cope with fake news during this crisis should be considered by the government and the health authorities. Also, it is recommended for the health authorities to be more active in social media, especially during the outbreak of diseases to disseminate accurate information and factual news [4].

Many situations in healthcare, especially pandemics, require effective crisis communication. Each leader's response will test their resolve and their effectiveness [5]. The government has to respond and solve the public health crisis. Indonesia is one of the countries exposed to Covid19 , with geographically is an archipelago that makes it difficult for the government to centrally mitigate the spread of the virus. Therefore, the central government makes some policies by establishing the regional task force for the regional government to take a part. Regional government can make bylaws that are regularly changing but suitable with information system from central government on how to manage this global pandemic. Their focus is on ensuring the community safety from covid-19 spread and preventing misinformation.

While political leaders and media often describe COVID-19 as a crisis, the nature of this problem requires intergovernmental coordination and cooperation for effective policy responses. The main policy responses to COVID-19 have been to implement social distancing measures and to ensure that the healthcare system has resources necessary to treat patients. Decisions on social distancing measures derive from information and statistical models shared across jurisdictions [6]. Municipal decisions to shut these services and to enforce social distancing are thus crucial to a successful COVID19 response. Not only are these municipal policy decisions costly, but they also are depending on a shared commitment to decisive and coordinated action [7]. How the public and patients perceive the risk and respond to messages regarding risk mitigation relates to outrage. Social and cultural factors, immediacy, uncertainty, familiarity, personal control, scientific uncertainty and trust in institutions and media all shape acceptability of response. These outrage factors influence the everchanging public understanding of COVID-19 risk, as well as the public's acceptance of personal and societal mitigation strategies [8].

The spread of misinformation on social media in the context of crisis communication provides both challenges and opportunities for experts and officials to effectively communicate and influence these outrage factors. Malecki [8] point outs that social media offers an opportunity for experts to quickly convey true information about hazards, but offers others the opportunity to counter this with the spread of misinformation and exacerbate outrage. The regional government must be able to collaborate with various parties and make some policies in managing the crisis communication, so that can more reach the target both in terms of health and trusted information dissemination. Crisis communication planned carefully can play a critically important role in prevention and mitigation of pandemics over time by reducing anxiety and fear, supporting public adherence to mitigation strategies, reducing burden, and increasing the effectiveness of medical interventions [9] and [8].

The pace of the COVID-19 crisis has required management strategies to be chosen and implemented without the time for careful engagement with the public. One solution for this would be to establish national and international risk information and communication units tasked responding as soon as a potential crisis arises. To address the point raised earlier about communicating to groups with very different risk responses (freeze, flight, fight), centralised crisis communications should be complemented by decentralised hotlines and similar services, with staff trained to recognise the different groups and communicate accordingly [10].

\section{LITERATURE REVIEW}

Clear communication by leaders during a crisis is essential to limit harm and ultimately resolve the crisis. General axioms of crisis communication include preparation, communication plan development, and coordination of message through designated personnel. However, even in the best cases, critical information can be lost in communication and consequently place lives at risk [5]. Crisis communication ideally begins well before needed with a plan [5]. Thus, having clear objectives as to what to communicate is essential. Three fundamental goals during crisis communication include:

- To increase knowledge and understanding

- To enhance trust and credibility

- To minimize the negative impacts of fear and concern

In a crisis, the goal of reducing the adverse effects of the situation should guide communication and focus a team's attention [5].

A number of case studies have shown that when communication is led by credible scientists, the public's response to the risk and (and as a result, the containment of the outbreak) is often more successful than if communication is led solely by individuals who are not subject matter experts [9] and [8].Clear communication by leaders during a crisis is essential to limit harm and ultimately resolve the crisis. General axioms of crisis communication include preparation, communication plan development, and coordination of message through designated personnel [5]. As such, it is important for infectious diseases clinicians to be well prepared to lead risk communication during crises, in this case, the COVID-19 pandemic [8].

Crisis and emergency risk communication frameworks are currently being applied in the public health response to the coronavirus disease 2019 (COVID- 
19) pandemic to encourage public participation in disease prevention and containment [11]. The COVID-19 core group remains in constant communication to ensure the most up-to-date information is made available. Daily challenges include screening of new information from government agencies, creating a unified protocol for multiple points of entry into the health system, and maintaining an updated protocol with constantly evolving information [12]. We note that the effectiveness of many of the other SDH in reducing the burden of the COVID-19 pandemic hinges on effective communication, especially crisis and risk communication. Although many countries are adopting different communication strategies during the COVID-19 crisis, effective crisis and risk communication will lead to building trust, credibility, honesty, transparency, and accountability [13]

While news outlets have always played an important role in informing and shaping public perception of risk, social media has rapidly become a major driver of what the public understands and responds to. Experts can use social media in crisis response by rapidly spreading hazard information and helping inform the public and patients on actions they can take to mitigate risk. Public outrage driven by social media must be considered by experts to understand and deploy effective communication strategies aimed at mitigating and control of risks overtime [8]. While these larger social forces are difficult to control, the hazard plus outrage framework can help clinicians and public health experts remain trusted sources in the fight against COVID-19. In the global pandemic of COVID-19, providing the appropriate context during crisis communication directly affects the type of response individuals take to achieve appropriate resolution of the problem. In the COVID-19 pandemic response, how leaders communicate the problem determines how effective their constituents' response in addressing the problem will be [5],[8].

Irrespective of the stage of the pandemic in any country, including the stage with no confirmed case, the WHO checklist for RCCE has six domains for actions: (i) setting up, strengthening and managing risk communication systems, (ii) engendering and strengthening internal and partner coordination to harmonize messages and public communication recognizing each partners' strengths and outreach capacities, (iii) timely and effective public communication using appropriate channels and media that target different populations in countries, including ensuring that health professionals are aware of public concerns and have the required training to provide public health advice, (iv) active community engagement appropriate for different audiences including affected people, health care workers, political leaders and donors. For instance, adapting communication materials to accommodate different literacy levels, culture and relevant languages, (v) addressing uncertainty and perceptions, and managing misinformation, and (vi) continuous capacity assessment and capacity building for RCCE as the situation evolves. For example, ongoing training of different stakeholders such as leaders, responders, and spokespeople on RCCE guidance [13].

The risks associated with miscommunication during the COVID-19 pandemic are undoubtedly high, especially where trust and credibility, for instance, in authorities and governments are eroded. So, "communication process must contain elements of trust, credibility, honesty, transparency, and accountability for the sources of information. Importantly, we know that 'it is perceptions of risk, not actual risk, that determine how people respond to hazards'. So, as a critical SDH, governments must ensure that crisis and risk communications strategies engender trust in authority, dispel false and unverified news and information, and contribute to favourable decisions and actions to improve public and population health during the COVID-19 crisis [9].

\section{METHODS}

The research method used in this research is descriptive research with a qualitative approach that aims to determine Implementation of Government's Crisis Communication during Covid-19 pandemic. According to Cresswell (2016) Qualitative research is an inquiry process of understanding based on distinct methodological tradition of inquiry that explore a social or human problem. The researcher builds a complex holistic picture, analyzes word, reports detailed views of information and conducts the study in a natural setting [14]. Meanwhile, descriptive research is aimed at describing a state or phenomenon as it is [15]. The qualitative research chosen is a type of case study. In this study, researchers focused on the implementation of crisis communication carried out by the Karawang district government in handling Covid-19.

Data collection in this study was conducted in two ways: literature study and field studies. The literature study conducted in this study use the content analysis examines problems regarding policies and patterns of government crisis communication during the Covid-19 with data obtained from international and national journals, books, laws and regulations, government documents as well as booklets and guidebooks from Ministry of Health regarding the handling of Covid-19. Field Study in this research was implemented through observation and interview techniques, where the researcher observed and participated directly and interviewed the informants who had been determined in this study, namely the Task Force for the acceleration of covid-19 management, Karawang Regency.

\section{RESULTS AND DISCUSSIONS}

\subsection{Indonesian Government policies in handling covid-19}

The outbreak of the COVID-19 pandemic is a real threat to global health, a burden and a serious challenge for all 
countries including Indonesia. COVID-19 has led to the adoption of various public policies by the government, with various designs and various policy contents. Many strategies have been made by the government in overcoming this pandemic where the government has issued many policies as a responsive first step to minimize the wider spread of this virus. These policies were issued at both the central government and provincial government levels, which were then followed up by the city and district governments. The main policies for handling Covid in Indonesia are stated in Keputusan Presiden Nomor 7 Tahun 2020 (Presidential Decree Number 7 of 2020) about The Task Force to Accelerate the Handling of Covid-19 and Peraturan Pemerintah Nomor 21 Tahun 2020 (Government Regulation Number 21 of 2020) about Large-Scale Social Restrictions in the Context of Accelerating Handling of Covid-19. These policies are issued by central government that also used as the basis by local governments in order to formulate various efforts and policies in handling Covid-19 in its region.

As a first step, the Indonesian government through The Ministry of Health and The National Disaster Management Agency formed a National task force to accelerate the handling of covid-19. Then, the national task force team divided the areas affected by covid into 4 levels of zoning criteria with risk category indicators from the level of transmission or spread. The 4 levels of zoning criteria:

Table 1: Level zoning criteria of the spread of covid-19 in Indonesia [16].

\begin{tabular}{|c|c|c|}
\hline $\begin{array}{c}\text { Zoning } \\
\text { Category }\end{array}$ & Indicators & $\begin{array}{c}\text { The government to } \\
\text { do }\end{array}$ \\
\hline $\begin{array}{l}\text { Green } \\
\text { Zone } \\
\text { (Not } \\
\text { Affected) }\end{array}$ & $\begin{array}{l}\text { No positive } \\
\text { covid-19 } \\
\text { infection found, } \\
\text { the virus spread } \\
\text { is controlled, the } \\
\text { risk of spreading } \\
\text { remains in } \\
\text { isolation places, } \\
\text { periodic and } \\
\text { strict supervision } \\
\text { to prevent the } \\
\text { potential new } \\
\text { cases }\end{array}$ & $\begin{array}{l}\text { Strict check on } \\
\text { entrances to the area, } \\
\text { intensively doing } \\
\text { covid testing, } \\
\text { monitoring } \\
\text { population mobility, } \\
\text { attention to the } \\
\text { implementation of } \\
\text { standard health } \\
\text { protocols, business } \\
\text { and religious } \\
\text { activities are opened } \\
\text { normally, aggressive } \\
\text { contact tracing if } \\
\text { covid symptoms } \\
\text { found }\end{array}$ \\
\hline
\end{tabular}

Yellow The possibility of Communities can do Zone local activities outside (Low- transmission with high health Risk occurring is still protocols, aggressive Affected) high and possibly contact tracing if fast, household covid symptoms level found, maintain transmission can social distance occur, transmission for imported cause can happen quickly, controlled deployment clusters and not increase

\begin{tabular}{|c|c|c|}
\hline $\begin{array}{l}\text { Orange } \\
\text { Zone } \\
\text { (Medium- } \\
\text { Risk } \\
\text { Affected) }\end{array}$ & $\begin{array}{l}\text { Potential virus } \\
\text { not controlled } \\
\text { and high spread, } \\
\text { local } \\
\text { transmission and } \\
\text { imported case } \\
\text { may occur } \\
\text { quickly, new } \\
\text { clusters must be } \\
\text { monitored and } \\
\text { controlled by } \\
\text { testing } \\
\text { aggressive } \\
\text { tracing }\end{array}$ & $\begin{array}{l}\text { People are advised to } \\
\text { stay at home and } \\
\text { work from home, } \\
\text { maintain social } \\
\text { distance in all } \\
\text { aspects, passenger } \\
\text { restriction and strict } \\
\text { health protocols on } \\
\text { public transport, } \\
\text { public places and } \\
\text { education facilities } \\
\text { are closed, limited } \\
\text { open business } \\
\text { activities }\end{array}$ \\
\hline $\begin{array}{l}\text { Red Zone } \\
\text { (High- } \\
\text { Risk } \\
\text { Affected) }\end{array}$ & $\begin{array}{l}\text { Virus spread are } \\
\text { not controlled, } \\
\text { local } \\
\text { transmission or } \\
\text { the spread of } \\
\text { covid among } \\
\text { local residents in } \\
\text { one area quickly, } \\
\text { the outbreak is } \\
\text { widespread and } \\
\text { many new } \\
\text { clusters in the } \\
\text { area }\end{array}$ & $\begin{array}{l}\text { More intensive } \\
\text { testing for covid } \\
\text { conducting contac } \\
\text { tracing on positive } \\
\text { cases, people mus } \\
\text { stay at home, trave } \\
\text { and } \\
\text { gatherings are no } \\
\text { allowed, publi } \\
\text { places, education } \\
\text { facilities, } \\
\text { business activitie } \\
\text { are closed, priority } \\
\text { for the use of healtl } \\
\text { facilities, }\end{array}$ \\
\hline
\end{tabular}
indoors and high health protocols is allowed, business and sports venues are opened under high health protocols, vulnerable groups remain at home, health service are opened normally

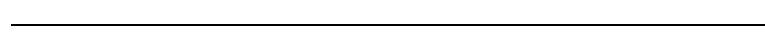

Zoning in these areas is based on data collection and studies as well as analysis from the National Task Force 
expert team. The zoning was determined using indicators that there are totally 15 main indicators, including public health indicators, which are divided into 11 epidemiological indicators, two public health surveillance indicators and two health service indicators.

\subsection{Crisis management policies of regional government Karawang Regency}

Indonesia is a country whose government system extends to the district level and provides autonomy rights for each district to make their own strategy to handling the crisis due to Covid-19. It is similar to Karawang Regency, one of the areas with a large number of Covid-19 cases and belonging to the yellow zone category. Karawang regency is an industrial city that mean has a high potential risk of spreading covid-19 because has many industrial areas that allowing foreign worker traffic in and out. The first case data confirmed positive for Covid-19 in Karawang Regency was recorded on March 24, 2020, where there were 5 people who were confirmed positive and one of them was the Regent of Karawang, dr. Cellica Nurrahdiana. This is a bad condition, in which the leader must get quarantine during the covid-19 which affects to local government in making policies for handling covid-19 in Karawang Regency. But, this condition can be overcome with the cooperation among all elements and good communications pattern from leader to team and team to leader using the all communication media platform.

The Covid-19 case in Karawang Regency has increased with the emergence of various new clusters based on the last monitoring data on August 28, 2020 [17]. Total number of positive Covid Confirmations is 242 people, 138 people recovered and in the care of 96 people, with a total number of suspected 6,137 people, a total probable of 59 people and a total of 1655 close contacts [18]. In the context of preventing and handling Covid 19 in Karawang Regency, the local government has made pace with issued several policies like the issuance of Surat Edaran Bupati Karawang Nomor (Karawang Regent's Circular Number) 440/1604/Dinkes about followed up to prevent of covid-19 spread with establish a task force to accelerate the handling of Covid 19.

The task force to accelerate the management of covid-19 consists of various elements and involves various regional work units in Karawang Regency, like the Local Government, National Army, Police, Health District Service, Communication and Information District Service, Regional Disaster Management Agency, Social District Service and health volunteers. The task force to accelerate the handling of covid 19 in the regions responsible to coordinate and control the implementation of activities to accelerate the management of covid-19, including informing the public about the prevention, management and development of the Covid 19 case. It can create transparency of information related to developments of the Covid case in the regions.

\subsection{Government crisis communication in Karawang Regency during covid-19}

So far, the steps taken by the Task Force for the Acceleration of Handling Covid-19 have been guided by Handbook for Handling Covid-19 revision 5, The Indonesia Ministry of Health and conducting by 4T Stages: testing, tracing, treating, and telling [19]. In this article, we will discuss the implementation of government crisis communication as a "telling" stage strategy by the Karawang regency government. Based on the guidebook for handling covid-19, "telling" stage has an important role in handling covid-19, where the task force informs the public about the prevention, handling and development of the Covid 19 case as an effort to minimize misinformation that develops in the community.

Implementation of the government crisis communication in order to inform the community in Karawang Regency about the handling and development of the Covid-19 case, the Task Force, which is directly chaired by the regent, appointed a team of expert spokespersons to convey information. The spokes team consists of credible scientists like doctors whose appointment is based on expertise in infectious disease cases. Information dissemination which led by experts will make the risk communication related to Covid-19 clearly and trusted by the public. The government of Karawang Regency implements one gate information system to prevent the spread of hoax information about covid-19 which can cause chaos in the community. Through the Spokesperson for the Karawang Regency Task Force and Communication and Information District Service (Diskominfo) conveyed information related to updating the data on the number of Covid-19 cases and their handling through a press conference.

The information provided to the public is accurate data based on the centralized information system at the Diskominfo "Command Center" which is used as a reference for data on the development of the Covid-19 cases. This data are get from monitoring result by the task force team 24 hours everyday with the real time application system[19]. And then, Diskominfo in Karawang regency responsible to make the press releases and creative content in social media platform to gain more community become aware about the covid spread and the risks without any scares impression [20].

Information dissemination related to the development and handling of Covid-19 in Karawang Regency uses other media such as mass media i.e. newspapers, local radio, and local TV Channel in Karawang such as Berita TV, and also via social media 
platform like instagram account of diskominfo karawang regency i.e. @diskominfokrwkab and @ satgascovid19.karawang which can access easily by everyone. In addition, the task force also give the direct outreach to public regarding the prevention and handling of Covid-19. Delivery process of this information is not only gave at the district level but also at the sub-district and village levels by the task force team at the sub-district and village levels. Furthermore, the Karawang regency task force team provided separate outreach directly specific to industrial estates [19]. These various ways do by the government aimed to information is spread thoroughly and becomes a common understanding.

Government crisis communication in Karawang Regency is not only implemented for the dissemination of information about Covid to the public but also for coordination between local government elements who work together to handle regional crises cause this virus. They have a common communication forum with whatsapp group to report the latest information and progress to leader regarding the performance of crisis management. The task force of Karawang regency has good communication flows with regularly coordination make leaders aware of the latest conditions so can make them faster into policy making during crisis [19]. Leaders always monitor every progress about covid cases and the impacts to Karawang regency community.

\section{CONCLUSION}

The Indonesian government's strategy to deal with the crisis due to Covid 19 is carried out by forming a special task force team to accelerate the handling of Covid-19 from the national to the regional level. Likewise, in Karawang Regency the task force doing a great work for preventing the hoax information with implementation of the government crisis communication. The local government of Karawang Regency enforces one gate information system with the "command center" by Diskominfo in Karawang Regency. The regional task force chaired the spokesperson for handling covid-19 with the credible scientists like doctors whose appointment are based on expertise in infectious disease cases. Information dissemination which led by experts will make the risk communication related to Covid-19 clearly and trusted by the public. The government of Karawang regency also used any media platform for update their information about development and handling of covid-19 like newspaper, radio, TV and social media platform to public access easily. With the government's crisis communication hopefully the communities, especially in Karawang Regency, can be safe from the hoax information that can made chaos and overpanic. And it also increase the public awareness about covid-19 and the risks, so the virus spread can be controlled.
There are several obstacles experienced by the Covid Task Force in Karawang in doing their duties. One of the main things is the different aspects in public awareness of the risk of spreading covid. In communities with a low level of awareness making the implementation of government crisis communication in Karawang district less effective. Many people not heed the warnings or information from the government which results in increasing the number of positive cases of Covid in Karawang district. Even so, the implementation of this government crisis communication must be keep move so there is an increase the awareness in the community and make a positive impact on preventing the spread of Covid does not spread further.

Implementation of crisis communication by the local government of the Karawang district is a strategy to prevent the spread of hoaxes which could make the public ignore about information in prevention and handling of Covid 19 which was socialized by covid management task force. In the current crisis condition, government communication patterns are needed to be able to provide credible and reliable information. Clear communication messages about Covid-19 through official media and social media are important contributors to changing people's behavior towards government policies in terms of prevention and handling of Covid-19 such as wearing masks, washing hands, and maintaining social distancing.

\section{ACKNOWLEDGMENT}

This research is made possible by support and assistance from many people and institutions. Firstly, we would like to thank the government of Karawang Regency especially Regional task force for handling covid-19 team and Communication and information officials of Karawang Regency for their willingness to be research informants. We are also say thank you to the faculty of social and political science, Universitas Singaperbangsa Karawang for supporting this research.

\section{REFERENCES}

[1] E. Mogaji, "Impact of Covid-19 on Transportation In Lagos, Nigeria," Transportation Research Interdisiplinary Perspectives, 2020.

[2] M. Sigala, "Impacts and Implications For Advancing and Resetting Industry and Research," Journal of Business Research, 2020. 
[3] V. Venkatesh, "Impacts of Covid-19: A Research Agenda to Support People in Their Fight," International Journal and Information Management, 2020.

[4] A. Abidoli, "Gossip, rumors and the Covid-19 Crisis," University of Liverpool Library. https://doi.org/10.1017/dmp.2020.272, 2020.

[5] H. Tetteh, "A Leader's Guide to Crisis Communication : Lesson From Ebola for Covid19," Military Medicine, 2020.

[6] P. \&. R. S. Mireille, "COVID-19 as a Complex Intergovernmental Problem," Canadian Journal of Political Science, Cambridge University Press. https://doi.org/10.1017/S0008423920000281., pp. $1-5,2020$.

[7] A. \&. J. L. David, "Measuring and Comparing Municipal Policy Responses to COVID-19," Canadian Journal of Political Science Cambridge University.

https://doi.org/10.1017/S000842392000044X, pp. 1-12, 2020.

[8] K. K. \&. J. S. N. Malecki, “Crisis Communication and Public Perception of COVID-19 Risk in the Era of Social Media," Oxford University Press For Infectious Diseases Society of America, 2020.

[9] G. DC, "Risk Communication for Public health emergencies," Annu Rev Public Health, vol. 28, pp. 33-54, 2007.

[10] C. A, "Covid-19 Risk Governance : Drivers, Response and Lessons to be Learned," Journal of Risk Research, Taylor and Francis Group. https://doi.org/10.1080/13669877.2020.1760332, 2020.

[11] W. e. M.L, "Leveraging community engaged research partnerships for crisis and emergency risk communication to vulnerable populations in the COVID-19 pandemic," Journal of Clinical and Translational Science. https://doi.org/10.1017/cts.2020.47, 2020.

[12] M. Maxam, "Development and Implementation of a COVID-19 Disease Response Protocol at a Large Academic Medical Center," https://doi.org/10.1017/dmp.2020.166, 2020.
[13] O. \&. J. E. Ataguba, "Social determinants of health: the role of effective communication in the COVID-19 pandemic in developing countries," Global Health Action. https://doi.org/10.1080/16549716.2020.1788263, vol. $13,2020$.

[14] J. Cresswell, Research Design : Pendekatan Metode Kualitatif, Kuantitatif dan Campuran, Yogyakarta: Pustaka Pelajar, 2016.

[15] Sudaryono, Metodologi Penelitian, Depok: Raja Grafindo, 2017.

[16] B. N. P. Bencana. [Online]. Available: www. bnpb.go.id. [Accessed 25 August 2020].

[17] S. Covid-19, "covid19.karawangkab.go.id," [Online]. Available: covid19.karawangkab.go.id. [Accessed 30 August 2020].

[18] D. K. d. Informasi. [Online]. Available: diskominfo.karawangkab.go.id. [Accessed 30 Agustus 2020].

[19] Yayuk, Interviewee, Communication Crisis. [Interview]. 24 August 2020.

[20] P. d. Diskominfo, Interviewee, Information about Covid 19 In Karawang Regency. [Interview]. 29 August 2020. 